\title{
The Amino Acid Sequence of a Human $x$ Light Chain
}

\author{
By CELIA P. MILSTEIN aNd E. V. DEVERSON \\ Agricultural Research Council Institute of Animal Physiology, \\ Babraham, Cambridge CB2 $4 A T, U . K$.
}

(Received 25 February 1971)

\begin{abstract}
The amino acid sequence of the light chain of the myeloma protein Dee was studied. The light chain is of the $\kappa$ type and of subgroup I. The variable part contains some substitutions that are unique and also some that have been observed already in other $\kappa I$ chains (repeated variants). Based on these repeated variants a subdivision of the $\kappa \mathrm{I}$ subgroup is proposed.
\end{abstract}

Immunoglobulins $\mathrm{G}$ are made up of two identical light chains and two identical heavy chains covalently linked by interchain disulphide bonds (Porter, 1962). Immunoglobulin G can be of either $\mathrm{K}$ or $\mathrm{L}$ type according to the nature of the light chain ( $\kappa$ or $\lambda$ respectively). Chemically, light chains isolated from normal human serum are a very heterogeneous population of $\kappa$ and $\lambda$ molecules but in some pathological conditions myeloma proteins are produced and homogeneous light-chain preparations can be easily obtained. Each light chain is made up of two sections of approximately equal length. The $\mathrm{C}$ region, towards the carboxyl end, has a constant and identical sequence in different light chains of the same type; the other, the V region, the $N$-terminal section, has a variable sequence. Within the variability of the $V$ region there is a high degree of similarity among some of the light chains of the same type and this led to the classification of the known human $\kappa$ and $\lambda$ chains into families or subgroups (Milstein \& Pink, 1970). One of the substitutions (arginine/glutamine at position 24) observed in some proteins of the $\kappa I$ subgroup was studied in the serum of normal individuals (Milstein, Milstein \& Feinstein, 1969) and it appeared to define two distinct populations of molecules coded by non-allelic genes. From the three proteins presented in that work, Dee and Car were selected for sequence determination in order to help define the two populations mentioned above. In the present paper, a detailed study of the amino acid sequence of the light chain of one of these proteins, Dee, is reported. The light chain of this myeloma protein contains some unique substitutions in the $\mathrm{V}$ region that have not been reported previously. It also contains some other substitutions previously observed in proteins of the $\kappa \mathrm{I}$ subgroup. It seems that the glutamine/arginine substitution found at residue 24 is not the only one to define the two populations but that there are other linked alternative residues.

\section{MATERIALS AND METHODS}

The myeloma protein was kindly provided by Dr B. Frangione. Carboxymethylated chains were prepared by the procedure of Fleishman, Pain \& Porter (1962) by using iodoacetate as the blocking agent and fractionating on a Sephadex G-100 column in 5\% (v/v) formic acid.

Total reduction and alkylation with iodo $\left[{ }^{14} \mathrm{C}\right]$ acetate. This was carried out on the separated light chains as described by Milstein (1968a). The solution containing the reduced and carboxymethylated light chains was dialysed against large volumes of $1 \%(w / v) \mathrm{NH}_{4} \mathrm{HCO}_{3}$ and then digested with trypsin. When digestion with pepsin instead of trypsin was to be done, the solution containing the treated light chain was dialysed against $0.01 \mathrm{M}-\mathrm{HCl}$.

Digestion of protein and peptides with proteolytic enzymes. Trypsin and chymotrypsin digestions were done in $1 \%$ (w/v) $\mathrm{NH}_{4} \mathrm{HCO}_{3}, \mathrm{pH} 8.0$ at $37^{\circ} \mathrm{C}$, and stopped by drying in a desiccator two or three times until free of salt.

For tryptic digestion of the light chain, an enzyme/substrate ratio of 1:100 (by wt.) was used for $4 \mathrm{~h}$ and the final concentration of protein was approx. $9 \mathrm{mg} / \mathrm{ml}$. The digest ( $100 \mathrm{mg}$ of light chain) was fractionated on a column $(120 \mathrm{~cm} \times 2.5 \mathrm{~cm})$ of Sephadex G-50 equilibrated with $0.5 \% \mathrm{NH}_{4} \mathrm{HCO}_{3}$. The fractions obtained were freezedried. Tryptic digestion of peptide $\mathrm{Pbll}$ was done on approx. $120 \mathrm{nmol}$ dissolved in $1 \% \mathrm{NH}_{4} \mathrm{HCO}_{3}$, by using $20 \mu \mathrm{g}$ of trypsin; digestion went on for $16 \mathrm{~h}$ at $37^{\circ} \mathrm{C}$. The trypsin used was $2 \times$ crystallized (batch TR3F 6401) from Worthington Biochemical Corp., Freehold, N.J., U.S.A.

Peptic digestion was carried out in $0.01 \mathrm{M}-\mathrm{HCl}$ (enzyme/ substrate ratio $1: 100$, by wt.) for $18 \mathrm{~h}$ at $37^{\circ} \mathrm{C}$; the final concentration of protein was approx. $9 \mathrm{mg} / \mathrm{ml}$.

Chymotryptic digestion of fraction TI-I was performed on approx. $1.2 \mu \mathrm{mol}$ dissolved in $0.2 \mathrm{ml}$ of $1 \% \mathrm{NH}_{4} \mathrm{HCO}_{3}$ and $40 \mu \mathrm{g}$ of chymotrypsin was used. For peptide TIIA2, about $120 \mathrm{nmol}$ of peptide was dissolved in $100 \mu \mathrm{l}$ of $1 \%$ $\mathrm{NH}_{4} \mathrm{HCO}_{3}$ and $25 \mu \mathrm{g}$ of chymotrypsin was added. Both digestions were carried out for $6 \mathrm{~h}$.

Performic acid oxidation. The method of Hirs (1956) was used. Oxidation was for $45 \mathrm{~min}$ at room temperature and the reaction mixture was dried.

High-voltage paper electrophoresis. This was carried out as described by Milstein \& Feinstein (1968). 
Table 1. Amino acid composition of light chain from protein Dee

Abbreviation: $\mathrm{CySO}_{3} \mathrm{H}$, cysteic acid.

Amount of amino acid recovered ( $\mu \mathrm{mol})$

\begin{tabular}{|c|c|c|c|c|c|c|}
\hline & Oxidized sample & & Unoxidized & & & \\
\hline$(24 \mathrm{~h}$ & $(72 \mathrm{~h}$ & $(98 h$ & $(24 h$ & Best & Best & sequence + \\
\hline
\end{tabular}

hydrolysis) hydrolysis) hydrolysis) hydrolysis) hydrolysis)* value ${ }^{*}$ valueł (Fig. 5)

\begin{tabular}{|c|c|c|c|c|c|c|c|c|}
\hline Lys & 7.1 & 6.9 & 6.3 & 7.4 & 7.0 & 7.0 & 13.5 & 14 \\
\hline His & 1.0 & 1.6 & 1.1 & 1.2 & 1.0 & 1.0 & 2.0 & 2 \\
\hline Arg & 3.1 & 3.4 & 3.2 & 3.6 & 2.9 & 3.1 & 6.0 & 6 \\
\hline $\mathrm{CySO}_{3} \mathrm{H}$ & 2.3 & 2.3 & 1.9 & 2.5 & - & 2.3 & 4.4 & 5 \\
\hline Asp & 8.2 & 8.1 & 7.6 & 8.8 & 8.1 & 8.1 & 15.7 & 16 \\
\hline Thr & 9.9 & 9.6 & 7.8 & 8.7 & 9.9 & 10.4 & 20.0 & 20 \\
\hline Ser & 15.4 & 13.4 & 11.0 & 11.6 & 15.5 & 16.3 & 31.4 & 31 \\
\hline Glu & 11.8 & 11.1 & 10.9 & 11.9 & 11.7 & 11.5 & 22.3 & 22 \\
\hline Pro & 6.5 & 6.2 & 6.8 & 5.9 & 6.7 & 6.5 & 12.5 & 12 \\
\hline Gly & 7.5 & 7.4 & 7.1 & 7.8 & 7.4 & 7.4 & 14.3 & 14 \\
\hline Ala & 6.9 & 6.9 & 6.7 & 7.5 & 7.1. & 7.1 & 13.6 & 13 \\
\hline Val & 7.8 & 8.4 & 7.8 & 8.2 & 8.1 & 8.1 & 15.5 & 16 \\
\hline Met & - & - & - & - & 1.0 & 1.0 & 1.9 & 2 \\
\hline Ile & 2.5 & 2.6 & 2.3 & 2.6 & 2.6 & 2.5 & 4.9 & 4 \\
\hline Leu & 8.0 & 7.1 & 7.0 & 8.1 & 7.7 & 7.6 & 14.7 & 15 \\
\hline Tyr & 3.9 & 3.6 & 3.3 & 3.7 & 5.1 & 5.1 & 9.7 & 10 \\
\hline Phe & 4.6 & 4.5 & 4.2 & 4.8 & 4.7 & 4.6 & 8.9 & 8 \\
\hline Total & & & & & & & 211.3 & 210 \\
\hline
\end{tabular}

* Averages of two samples.

† 'Best value' is the average of different time-recoveries for amino acids other than Ser, Thr, Tyr and Met. The best values for Thr and Ser were the recoveries extrapolated to zero time of hydrolysis. The mean values obtained from the $24 \mathrm{~h}$ hydrolysates were taken as best values for Tyr and Met. Each analysis was performed on $60 \mu \mathrm{g}$ of freezedried light chain.

$\ddagger$ Not inoluding residues 48 and 49 shown in parentheses in Fig. 5, and the two tryptophan residues.

$\S$ This was calculated assuming a total of 207 residues excluding cysteine and tryptophan.

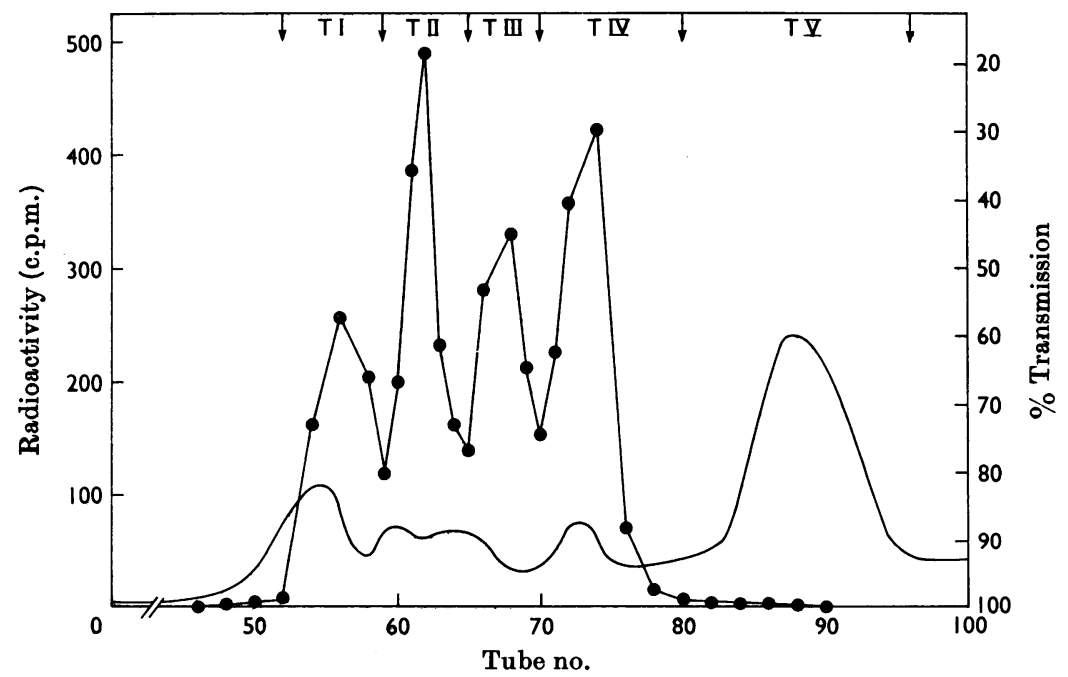

Fig. 1. Fractionation on Sephadex G-50 of a tryptic digest of fully reduced light chain of protein Dee blocked with iodo $\left[{ }^{14} \mathrm{C}\right]$ acetate. Fractions $(4 \mathrm{ml})$ were collected. - - $E_{280}$ in arbitrary units obtained in the LKB recorder attached to an LKB 8300 Uvicord spectrophotometer; •, radioactivity (c.p.m./10 $\mu$ l of eluate). 
Table 2. Peptides obtained in tryptic fractions

In 'puriflcation procedure' the numbers refer to the $\mathrm{pH}$ at which high-voltage paper electrophoresis was done and BAWP refers to desoonding paper chromatography. Mobilities at $\mathrm{pH}$ 6.5 were measured relative to aspartic acid $(0$ fford, 1966). The basic peptides are indicated by a negative sign. Mobilities at $\mathrm{pH} 3.5$ were expressed relative to the mobility of alanylglycine in the same run, taking as mobility zero the midpoint of the taurine spot.

Amino acid composition ( $\mathrm{mol}$ of amino acid/mol of peptide)

\begin{tabular}{|c|c|c|c|c|c|c|c|c|c|c|}
\hline \multirow{3}{*}{\multicolumn{2}{|c|}{$\begin{array}{c}\text { Peptide } \\
\text { Puriflcation } \\
\text { procedure }\end{array}$}} & \\
\hline & $\cdots$ & TI-IIIN & TI-IIIb & TIIA2 & TIIN & TIIA1 & TIIIR1 & TIIIR2 & TIVB1N & TIVB1A \\
\hline & $\cdots$ & $\begin{array}{c}\text { 6.5, } \\
\text { BAWP }\end{array}$ & 6.5 & $6.5,3.5$ & $\begin{array}{c}\text { 6.5, } \\
\text { BAWP, } \\
\mathbf{3 . 5}\end{array}$ & $\begin{array}{c}\text { 6.5, } \\
\text { BAWP, } \\
\mathbf{3 . 5}\end{array}$ & $\begin{array}{c}\text { BAWP, } \\
\mathbf{3 . 5}\end{array}$ & $\begin{array}{l}\text { BAWP, } \\
6.5,3.5\end{array}$ & $\begin{array}{l}\text { BAWP, } \\
6.5,3.5\end{array}$ & $\underset{6.5}{\text { BAWP, }}$ \\
\hline Mobllity at pस 6.5 & $\ldots$ & $\mathbf{0}$ & -0.33 & 0.15 & 0 & 0.08 & 0 & 0.18 & $\mathbf{0}$ & 0.99 \\
\hline Mobility at pH 3.5 & $\cdots$ & $\overline{T h r}$ & $\overline{T h r}$ & 0.16 & 0.58 & 0.42 & 0.82 & 0.13 & 1.50 & $\overline{1}$ \\
\hline$N$-Terminus & $\cdots$ & Thr & Thr & Asp & Val & Thr & Val & Ser & Glu & Gly \\
\hline Lys & & - & 1.0 & - & 1.0 & 1.0 & - & - & 1.0 & - \\
\hline His & & - & - & - & 1.0 & - & - & - & - & - \\
\hline Arg & & - & - & 0.9 & - & - & 1.2 & 1.1 & - & - \\
\hline CMCyst & & - & - & - & 0.7 & - & 0.7 & 0.7 & - & 0.7 \\
\hline Asp & & - & - & 2.0 & - & 1.0 & - & 2.1 & 一 & - \\
\hline Thr & & 1.8 & 1.9 & 0.9 & 1.9 & 0.8 & 1.8 & 1.0 & - & - \\
\hline Ser & & - & - & 4.7 & 1.9 & 1.9 & - & 1.8 & - & - \\
\hline Glu & & - & - & 1.9 & 2.1 & 2.0 & - & - & 1.0 & 1.1 \\
\hline Pro & & 1.1 & 1.1 & 1.1 & 1.0 & 3.0 & - & 1.1 & - & - \\
\hline Gly & & - & 2.1 & 1.1 & 1.1 & 一 & - & 1.1 & - & 0.9 \\
\hline Ala & & - & - & 1.1 & 1.0 & 2.1 & - & 1.1 & 1.1 & - \\
\hline Val & & - & - & 1.0 & 3.0 & 2.2 & 0.9 & 1.8 & - & - \\
\hline Met & & - & - & 0.7 & - & - & - & - & - & - \\
\hline Ilo & & - & - & 0.8 & - & 1.0 & 0.9 & - & - & - \\
\hline Leu & & - & - & 1.0 & 1.1 & 1.0 & - & 2.0 & - & - \\
\hline Tyr & & 0.9 & - & - & 0.7 & 一 & - & 1.0 & - & - \\
\hline Phe & & - & 1.0 & - & - & 1.8 & - & 1.0 & - & - \\
\hline $\begin{array}{r}\text { Peptide } \\
\text { Puriffation }\end{array}$ & $\ldots$ & TIVB1b & TIVB2N & TIVB2A & TIVB2bl & TIVB2b2 & TVb1-1 & TVb1-2 & TVb1' & TVb2 \\
\hline $\begin{array}{l}\text { Purincation } \\
\text { procedure }\end{array}$ & ... & $\underset{6.5}{\text { BAWP, }}$ & $\begin{array}{l}\text { BAWP, } \\
6.5,3.5\end{array}$ & $\begin{array}{l}\text { BAWP, } \\
\text { 6.5, 3.5 }\end{array}$ & $\underset{6.5}{\text { BAWP, }}$ & $\underset{6.5}{\text { BAWP, }}$ & $\begin{array}{c}\text { 6.5, } \\
\text { BAWP, } \\
\mathbf{3 . 5}\end{array}$ & $\begin{array}{c}\text { 6.5, } \\
\text { BAWP, } \\
\mathbf{3 . 5}\end{array}$ & $\begin{array}{c}\text { 6.5, } \\
\text { BAWP }\end{array}$ & $\begin{array}{l}\text { 6.5, } \\
\text { BAWP }\end{array}$ \\
\hline Mobility at pH 6.5 & $\ldots$ & -0.35 & 0 & 0.36 & -0.30 & -0.50 & -0.33 & -0.33 & -0.33 & -0.63 \\
\hline Mobility at pH 3.5 & $\ldots$ & - & 0.14 & 0.90 & - & - & 0.53 & 0.72 & - & - \\
\hline$N$-Terminus & $\ldots$ & Ala & Val & Ala & Ser & Ala & Tyr & Val & Ser & His \\
\hline Lys & & 1.0 & - & 1.0 & - & 1.0 & 2.1 & 1.0 & - & 1.1 \\
\hline His & & - & - & - & - & - & - & - & - & 1.0 \\
\hline Arg & & - & 1.0 & - & 1.1 & - & - & - & 1.0 & - \\
\hline CMCys $\dagger$ & & - & - & - & - & 一 & - & - & - & - \\
\hline Asp & & 1.0 & - & 1.0 & - & - & 0.8 & - & 1.1 & - \\
\hline Thr & & - & 1.0 & - & - & - & - & - & - & - \\
\hline Ser & & 1.0 & - & - & 1.8 & - & - & - & 0.9 & - \\
\hline Glu & & 1.1 & 1.0 & 1.1 & - & - & 2.1 & 1.0 & - & - \\
\hline Pro & & - & - & - & 1.1 & 1.0 & 1.1 & - & - & - \\
\hline Gly & & 1.0 & - & - & 1.0 & - & 1.1 & - & - & - \\
\hline Ala & & 1.0 & - & 0.9 & - & 1.0 & - & - & - & - \\
\hline Val & & 1.0 & 1.0 & - & 1.0 & - & - & 1.0 & - & - \\
\hline Met & & - & 1.0 & - & - & - & - & - & - & - \\
\hline Ile & & - & - & - & - & - & - & - & - & - \\
\hline Leu & & - & - & - & - & - & 1.0 & - & - & - \\
\hline Tyr & & - & - & 1.0 & - & - & 1.9 & - & - & - \\
\hline Phe & & - & - & - & - & - & - & - & 1.0 & - \\
\hline
\end{tabular}

* Amino acid composition of a $90 \mathrm{~h}$ hydrolysate.

$\dagger$ Abbreviation: CMCys, S-carboxymethylcysteine.

Paper chromatography. Descending paper chromatography was carried out in BAWP (butan-1-ol-acetic acid-water-pyridine, 15:3:12:10, by vol.).

Identification and location of peptides on paper. The radioactive peptides were located by radioautography. The non-radioactive peptides were located by dipping a strip of paper in ninhydrin-cadmium reagent (Heilmann, Barrollier \& Watzke, 1957). Sometimes the chlorine reaction (Reindel \& Hoppe, 1954) and the specific colour tests for peptides containing tyrosine (Jepson \& Smith, 1953), arginine (Yamada \& Itano, 1966; Sakaguchi, 1925) and proline (Milstein, 1966a) were used. Peptides were eluted from the paper with $1 \%$ acetic acid.

Amide residues were identified from the electrophoretic mobility of the peptides (Offord, 1966).

Total acid hydrolysis. Peptide samples (15-30 nmol) were hydrolysed in $0.2 \mathrm{ml}$ of constant-boiling $\mathrm{HCl}$ in evacuated sealed tubes at $105^{\circ} \mathrm{C}$ for $19 \mathrm{~h}$, unless otherwise stated.

Amino acid composition. Quantitative amino acid analyses were performed in an automatic Locarte amino acid analyser (Spackman, Stein \& Moore, 1958). 


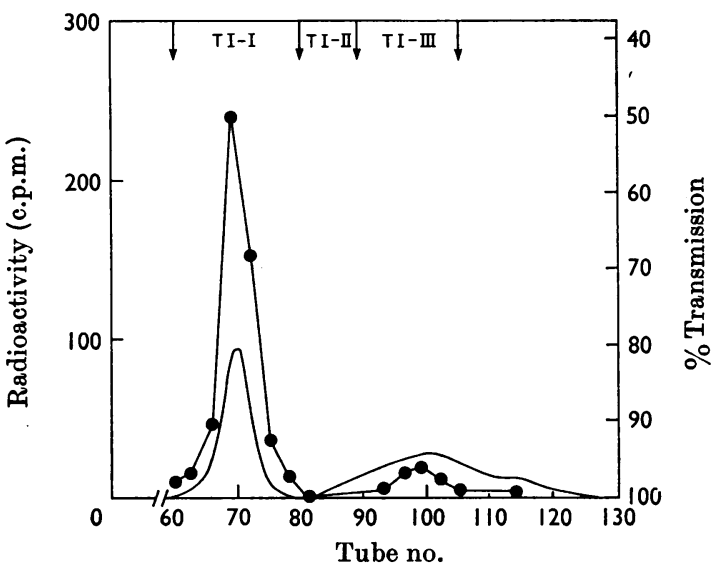

Fig. 2. Fractionation of fraction TI on Sephadex G-50. Fractions $(5 \mathrm{ml})$ were collected. - - $E_{280}$ in arbitrary units obtained in the LKB recorder attached to an LKB 8300 Uvicord spectrophotometer; •, radioactivity (c.p.m./ $10 \mu$ l of eluate).

Edman degradations and N-terminal analyses. The procedure described by Gray (1967) was used. The DNSamino acids were identified as described by Milstein \& Feinstein (1968) but the sensitivity was increased four times by using layers one-quarter of the area used by Woods \& Wang (1967).

C-Terminal analyses. A solution of carboxypeptidase A was used, as described by Ambler (1967).

Peptide nomenclature and abbreviations. Peptides were designated by a capital letter to indicate the enzyme used for the original hydrolysis of the light chain and for the further hydrolysis of the peptides. These capital letters were as follows: $T$, trypsin; C, chymotrypsin; $P$, pepsin. Electrophoretic behaviour at $\mathrm{pH} 6.5$ was indicated as A (acidic), $\mathrm{N}$ (neutral) and $\mathrm{b}$ (basic), and $\mathrm{B}$ indicates chromatography in BAWP. Small letters or numbers are used in alphabetical or numerical order so that ' $a$ ' or ' $l$ ' indicates the peptide with slowest mobility, either in chromatography or on electrophoresis. The sign $\rightarrow$ in figures or text underneath a residue denotes that the nature of the residue has been established by the dansylEdman procedure; - denotes a residue released by the action of carboxypeptidase $A$.

\section{RESULTS}

Amino acid analyses of light chain hydrolysed for different times were performed and the results are shown in Table 1.

\section{Tryptic digest of reduced and carboxymethylated light chain}

The radioactively labelled light chain of protein Dee after tryptic digestion and filtration through Sephadex G-50 gave four radioactive fractions and one non-radioactive (Fig. 1), which were called TI,
TII, TIII, TIV and TV. Purification, mobilities, $N$-terminal residues and amino acid composition of the peptides obtained from these fractions are shown in Table 2.

Fraction TI. The first fraction (TI; Fig. 1) was filtered again through Sephadex G-50 (Fig. 2). The first fraction of this second fractionation (TI-I) was not a pure peptide. Several attempts to purify it were unsuccessful and as result of them insoluble material was lost. The impure TI-I fraction was studied further by digestion with chymotrypsin and the second and third fractions (Fig. 2), TI-II and TI-III, were subjected to high-voltage paper electrophoresis at pH 6.5. Fraction TI-II was discarded because staining with ninhydrin did not show well-defined bands. Fraction TI-III yielded mainly one neutral (TI-IIIN) and one basic (TIIIIb) peptide (see Table 2). The sequence of peptide TI-IIIb established by the dansyl-Edman method was Thr-Phe-Gly-Pro-Gly-Thr-Lys. This peptide obtained by tryptic digestion was, however, a product of a chymotryptic split. It is apparent that the trypsin used was contaminated with chymotrypsin.

The chymotryptic digest of fraction TI-I was subjected to high-voltage paper electrophoresis at pH6.5 and the derived peptides were purified as detailed in Table 3. This table also shows the amino acid composition and $N$-terminal residues of the obtained peptides. The partial sequence of peptide TI-ICA0 is shown in Fig. 3. The mobility of this peptide at pH 6.5 (Table 2) indicates that it has one charge. This means that one of the three acid residues is present as an amide, but it cannot be specified which of the three it is. Peptide TI-ICA3 includes peptide TI-ICA4 plus an extra residue, phenylalanine, at the $N$-terminal end. The partial sequences of the two peptides are shown in Fig. 3 and define the complete segment. The sequences of peptides TI-ICN2, TI-ICN3 and TI-ICN4 are also shown in Fig. 3. The amino acid compositions and $N$-terminal residues of peptides TI-ICA6a and TI-ICA6 $a^{\prime}$ suggest that they come from positions 150-169 and 150-165 respectively of the constant region (Putnam, Titani \& Whitley, 1966).

Fraction TII. This fraction was subjected to high-voltage paper electrophoresis at pH6.5 and further purified (Table 2) to give two peptides, TIIAl and TIIA2. The amino acid composition and $N$-terminal residue of TIIAl (Table 2) suggested that the peptide came from positions 109-126 (Putnam et al. 1966). This peptide was also found in fraction TI-I, since peptides TI-ICN2 and TI-ICA0 come from it (see Fig. 5). The $N$ terminal residue and amino acid composition of peptide TIIA2 suggested that it came from the $N$-terminal end of the chain (Hilschmann, 1967). To determine its sequence, the peptide was treated 


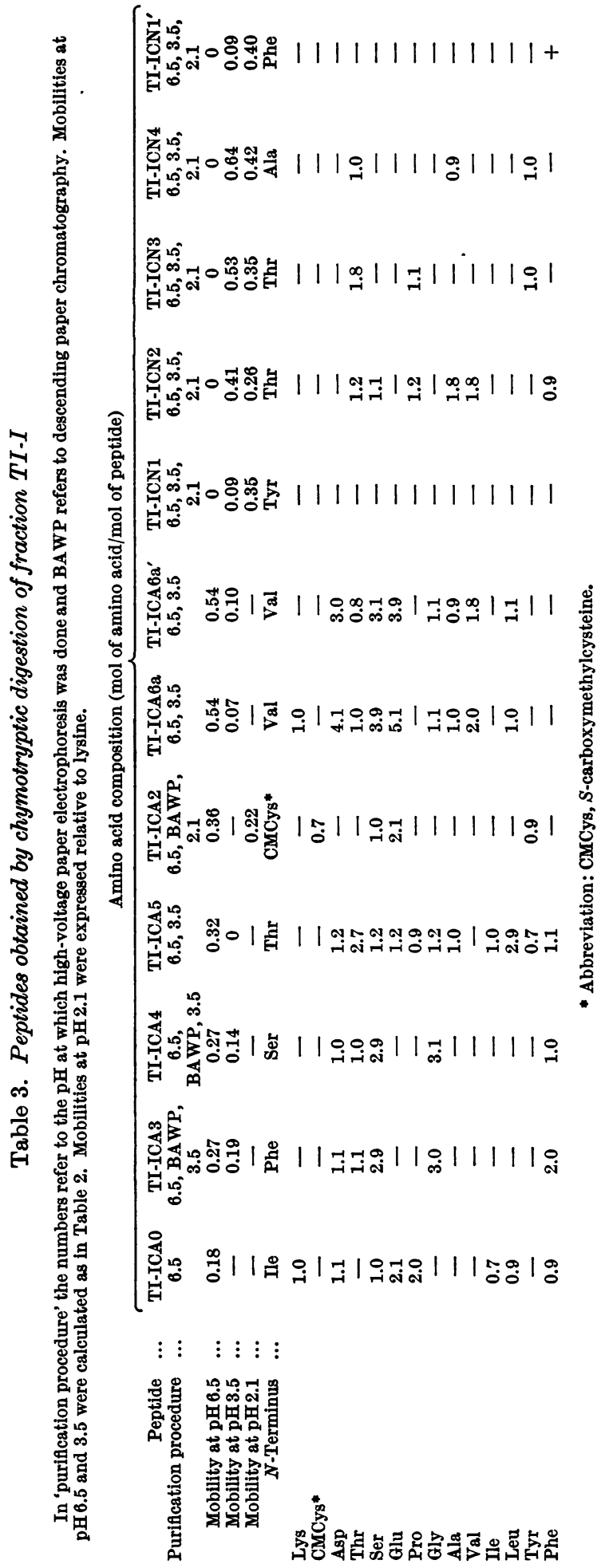


TI-ICA3 Phe-Ser-Gly-Ser-Gly (Ser,Gly) Thr (Asp) Phe

TI-ICA4 Ser(Gly,Ser,Gly) Ser-Gly-Thr-Asp-Phe

TI-ICA5 Thr-Leu-Thr-Ile-Ser-Gly-Leu (Leu, Pro, Glu, Asp, Phe, Ala, Thr, Tyr)

TI-ICA2 CMCys-GIx-GIx-Ser-Tyr

TI-ICN2 Thr-Val (Ala,Ala,Pro, Ser, Val) Phe

TI-ICN3 Thr-Thr-Pro-Tyr

TI-ICN4 Ala-Thr-Tyr

Fig. 3. Amino acid sequence of the chymotryptic peptides of TI-I, Residues in parentheses were not identified by sequence analysis. Abbreviation: CMCys, $S$-carboxymethylcysteine.

Table 4. Peptides obtained by chymotryptic digestion of peptide TIIA2

For details of purification procedure and mobilities, see Table 2.

\begin{tabular}{|c|c|c|c|}
\hline \multirow[b]{2}{*}{ Peptide } & \multirow[b]{2}{*}{$\cdots$} & \multicolumn{2}{|c|}{$\begin{array}{c}\text { Amino acid composition } \\
\text { (mol of amino acid/mol of peptide) }\end{array}$} \\
\hline & & TIICA & TIICN \\
\hline $\begin{array}{l}\text { procedure } \\
\text { Mobility at }\end{array}$ & $\cdots$ & 6.5 & 6.5, 3.5 \\
\hline $\begin{array}{r}\text { pH 6.5 } \\
\text { Mobility at }\end{array}$ & $\cdots$ & 0.26 & $\mathbf{0}$ \\
\hline $\begin{array}{r}\mathrm{pH} 3.5 \\
N \text {-Terminus }\end{array}$ & $\begin{array}{l}\ldots \\
\ldots\end{array}$ & $\overline{\text { Asp }}$ & $\begin{array}{l}1.11 \\
\text { Ser }\end{array}$ \\
\hline Arg & & - & 1.0 \\
\hline Asp & & 1.2 & 1.1 \\
\hline Thr & & 1.0 & - \\
\hline Ser & & 2.7 & 1.8 \\
\hline Glu & & 1.9 & - \\
\hline Pro & & 1.1 & - \\
\hline Gly & & 一 & 1.0 \\
\hline Ala & & - & 1.0 \\
\hline Val & & - & 1.0 \\
\hline Met & & 0.6 & - \\
\hline Ile & & 0.8 & - \\
\hline Leu & & 1.1 & - \\
\hline
\end{tabular}

with chymotrypsin (see the Materials and Methods section) and the product was subjected to highvoltage paper electrophoresis at pH 6.5. Two main peptides, one acid (TIICA) and another neutral (TIICN), were obtained. The mobilities, $N$. terminal residues and amino acid compositions of these peptides are shown in Table 4. Peptide TIICN contains arginine, and the $N$-terminus of peptide TIICA is the same as that of the original peptide TIIA2 (Figs. 4 and 5). The sequences of peptides TIICA and TIICN are shown in Fig. 4.

Fraation TIII. This fraction was subjected to descending paper chromatography in BAWP. There were two main radioactive peptides, TIIIR1 and TIIIR2. Peptide TIIIR1 was pooled with the radioactive peptide of fraction $I V$, which had the same mobility in BAWP, and purified by highvoltage paper electrophoresis at pH3.5 (Table 2). Its sequence is shown in Fig. 4.

Fraction TIV. This fraction, like the previous one, was subjected to descending paper chromatography in BAWP and the peptides obtained were further purified (Table 2). There were two radioactive peptides in this fraction. The one in larger yield was pooled with peptide TIIIRl (fraction TIII). By analogy with other $\kappa$ I chains, peptide TIVB1A comes from the $C$-terminal end of the light chain. Sequences of peptides TIVBlb, TIVB2N and TIVB2b1 are shown in Fig. 4. The peptides were located as follows : TIVBlb, positions 25-31; TIVB2N, positions 104-108; TIVB2bl, positions 56-61, by homology with other $\kappa I$ chains.

Fraction $T V$. This fraction was subjected to highvoltage paper electrophoresis at $\mathrm{pH} 6.5$ and the peptides obtained were further purified as detailed in Table 2. Peptide TVbl-1 and TVbl-2 were fluorescent under u.v. light, suggesting that both contained tryptophan. The amino acid composition and $N$-terminal residue of peptide TVb1-2 suggested 
TIIA2

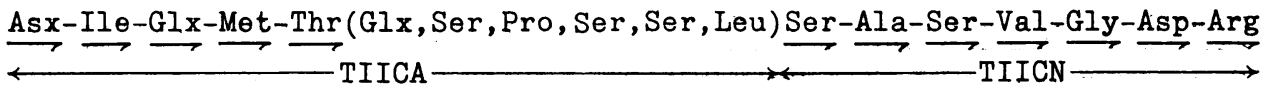

TIIIRI

TIVBIA Gly-Glu-CMCys

TIVBIb Ala-Gly-Gln-Ser-Val-Asn-Lys

TIVB2N Val-Glu-Met-Thr-Arg

TIVB2bl Ser-Gly-Val-Pro-Ser-Arg

TVbl-1 Tyr-Leu-Asn-Trp-Tyr-Gln-Gln-Lys-Pro-Gly-Lys

Fig. 4. Amino acid sequences of the tryptic peptides obtained in fractions TII, TIII, TIV and TV. The sequence of residues in parentheses has not been determined. Abbreviation: CMCys, $S$-carboxymethylcysteine.

that it came from positions $146-149$ of the constant region, which contains a tryptophan residue. The sequence of peptide TVbl-1 is shown in Fig. 4 and the peptide was located at positions $32-42$ by homology with other $\kappa \mathrm{I}$ chains. To identify the tryptophan (fourth residue from the $N$-terminal end) the DNS derivative was hydrolysed with $5 \mu \mathrm{g}$ of chymotrypsin overnight and the DNS-tryptophan identified by t.l.c. as used for the other DNS residues.

\section{Peptic digest of reduced and carboxymethylated light chain}

The reduced and carboxymethylated light chain $(50 \mathrm{mg})$ was digested with pepsin and the digest was fractionated by high-voltage paper electrophoresis at pH 6.5. Fig. 6 shows the radioactivity pattern obtained and the bands into which the paper was divided. These were three basic bands, a neutral band containing the insoluble material and five acidic bands. Table 5 summarizes the methods of purification, electrophoretio mobilities, amino acid compositions and $N$-terminal residues of the isolated peptic peptides. Fig. 7 shows the sequences determined for the isolated peptic peptides. The rest of this section will only contain remarks about sequence and charge of the peptides when necessary.

Peptides $\mathrm{Pbl}$ and $\mathrm{Pb} 3$ both have one basic and one acidic residue, histidine and glutamic acid respectively; therefore, as the peptide is basic, the acidic residue should be present as glutamine.

The sequence of peptide $\mathrm{Pb} 7$ was established (Fig. 7a). Peptide Pb8al had the same $N$-terminus as peptide Pb7 (Table 5). The amino acid composition of peptide Pb8al was the same as that of peptide $\mathrm{Pb} 7$ except that it had one more residue, valine; therefore this residue was placed at the $C$-terminal end of the peptide.

Peptide Pbll (Table 5) was digested with trypsin and the digest fractionated by high-voltage paper electrophoresis at pH 6.5 (Table 6). Carboxypeptidase $\mathrm{A}$ released leucine and valine from peptide $\mathrm{Pbl} 1$ at 15,30 and $45 \mathrm{~min}$ in ratios of $0.7 / 0.4,0.8 / 0.7$ and 1.0/0.8; therefore leucine was placed at the $C$ terminus. This confirmed that peptide PbliTN, valyl-leucine, was $C$-terminal. Peptide Pbll therefore included the $C$-terminus of peptide TVbl-1, the whole of peptide TIVB2b2 and two extra residues (see residues 36-47 in Fig. 5).

The amino acid composition of peptide $\mathrm{Pb12}$ (Table 5) contained all the amino acids forming peptide TIVB2bl plus two more residues, phenylalanine and lysine. The latter was $N$-terminal (Table 5) and phenylalanine was the only amino acid released by carboxypeptidase $A$ after $4 \mathrm{~h}$ of digestion.

Free tyrosine, phenylalanine, leucine and glycine were isolated along with the neutral peptides.

Peptide PA7b had $N$-terminal serine (Table 5) and so had peptide PAZ. The latter had all the amino acid residues of peptide PA7b plus one aspartic acid residue. The charge of peptide PA7b deduced from its mobility (Offord, 1966) was 1 and that of peptide PAZ was 2; therefore the aspartic acid residue of PAZ was present as aspartic acid. The glutamic acid residue of peptide PA13 was also present as glutamic acid, as deduced from mobility results (Table 5).

Fig. 5 shows the position of the purified peptides along the chain and the established amino acid sequence. The sequences of the residues that are between parentheses and separated by a comma 
Asx-Ile-Glx-Met-Thr-Gln-Ser-Pro-Ser-Ser-Leu-Ser-Ala-Ser-Val-Gly-Asp-Arg-Val-Thr-Ile-Thr-Cys-Arg-Ala-Gly-Gln-Ser-Val-Asn-Lys-Tyr-Leu-Asn-Trp-

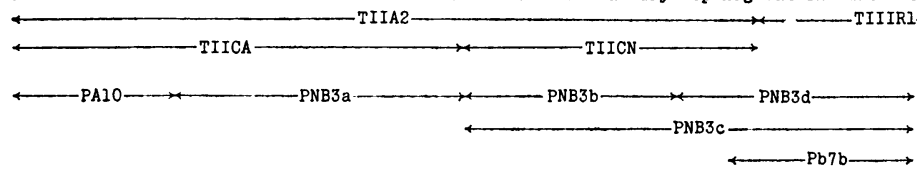

$\stackrel{40}{\text { Tyr-Gln-Gln-Lys-Pro-Gly-Lys-Ala-Pro-Lys-Val-Leu(Ile, Phe) Ala-Ala-Ser-Ser-Leu-Lys-Ser-Gly-Val-Pro-Ser-Arg-Phe-Ser-Gly-Ser-Gly-Ser-Gly-Thr-Asp- }} \underset{70}{60}$ $\stackrel{\text { TVbI-1 }}{\longrightarrow} \stackrel{\text { LIV }}{\longleftarrow}$

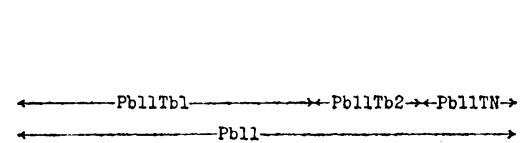

$\longleftrightarrow \mathrm{PbII} \longrightarrow$

Phe-Thr-Leu-Thr-Ile-Ser-Gly-Leu-Leu-Pro-Glu-Asp-Phe-Ala-Thr-Tyr-Tyr-Cys-Glx-GIx-
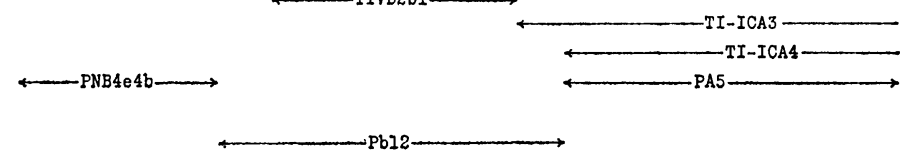

$\mathrm{Pbl2}$ 900100

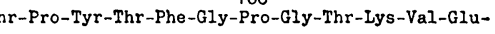

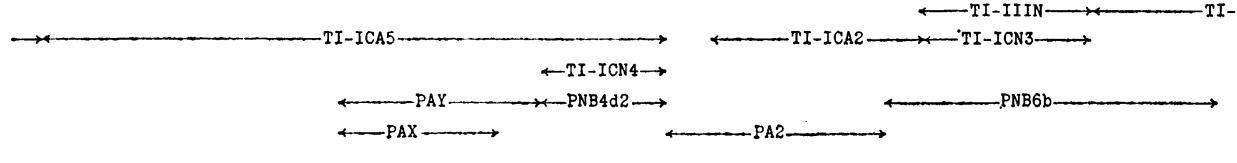

Met-Thr-Arg-Thr-Val (Ala, Ala)Pro(Ser, Val, Phe) Ile-Phe-Pro-Pro-Ser-Asp-Glu-Gln-Leu-Lys-Ser-Gly-Thr-Ala-Ser-Val (Val, Cys, Leu) Leu-Asn-Asn-Phe-Tyr- IIVB2N $\rightarrow$
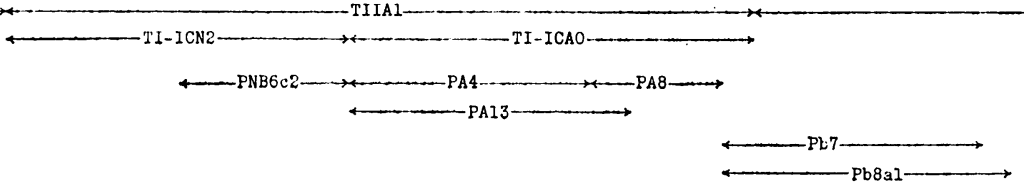

Pro-Arg-Glu-Ala-Lys-Val (Gln, Try) Lys-Val-Asx-Asx-Ala-Leu-GLx-Ser-Gly-Asx-Ser-Glx-Glx-Ser-Val-Thr-Glx-Glx-Asp-Ser-Lys-Asx-Ser-Thr-Tyr-Ser-Leu$\longrightarrow$ TIVBIN $\longrightarrow$

$-\mathrm{PNB3} \longrightarrow$

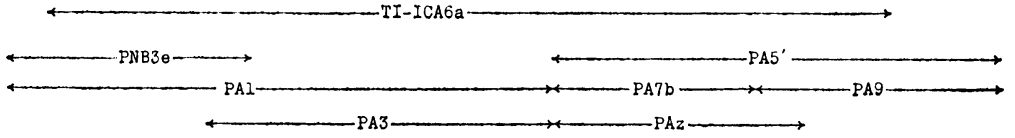

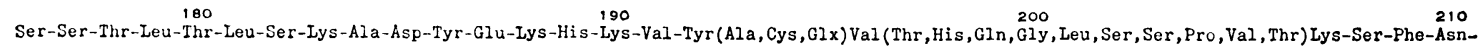

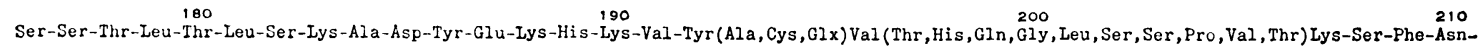

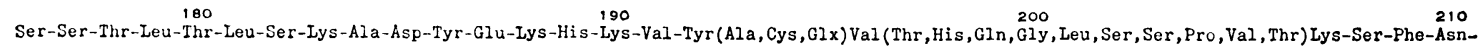

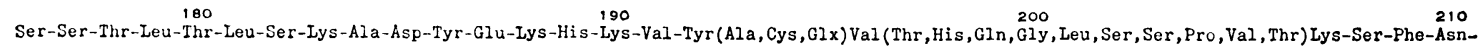

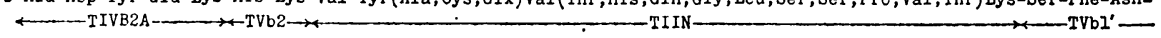

$\longleftarrow$ PNB2-1 $\rightarrow$ PNB7 $\longrightarrow$

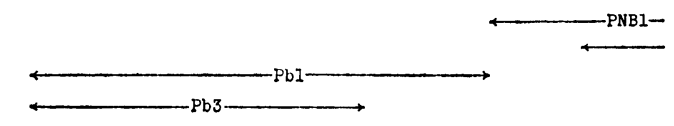

Arg-Gly-Glu-Cys

$\longrightarrow$ IIVBIA $\longrightarrow$

$\longrightarrow$

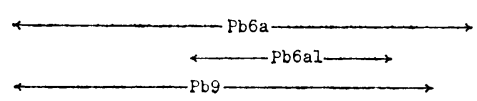

Fig. 5. Amino acid sequence of the light chain of protein Dee.

have not been determined and have been assigned by analogy with other $\kappa \mathrm{I}$ chains.

\section{DISCUSSION}

This work was done with emphasis on the sequencing of the variable part of the chain, since there are no problems about the amino acid sequence of the constant part, except for residue 191, which is associated with the genetic marker Inv (Milstein, 1966b; Baglioni, Alescio Zonta, Cioli \& Carbonara, 1966). This residue is valine (peptide TIIN; see Table 2) in protein Dee.

The total number of residues shown in the 'Best value' column of Table 1 is 211.3 owing to 
Lys $\longrightarrow$

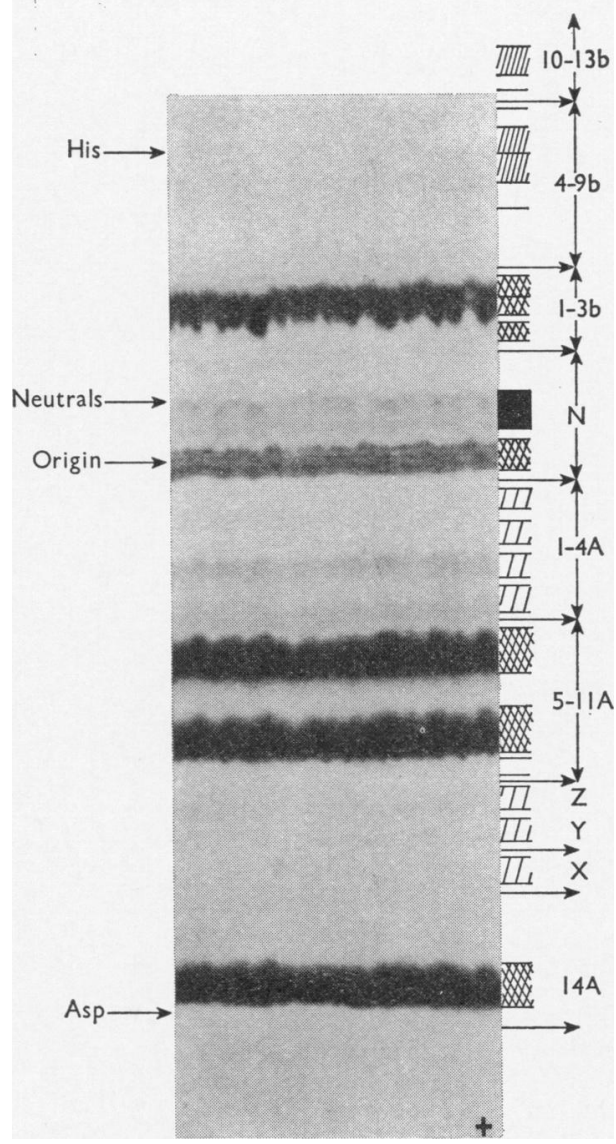

Fig. 6. Radioautograph obtained after electrophoresis at pH6.5 of a peptic digest of totally reduced light chain of protein Dee blocked with iodo $\left[{ }^{14} \mathrm{C}\right]$ acetate. The shadowed areas on the right are ninhydrin-positive bands and the intensities are, in decreasing order, $\square$, and $\square$ The arrows indicate the bands into which the paper was divided for further purification of the peptides contained in them.

the low value for cysteic acid, which, from the sequence, is 5 instead of 4.4. Taking this into account the total number of residues is 212 . However, this number in the column 'From sequence' (Table 1 ) is 210. Therefore there is a discrepancy of two residues between the two column totals, i.e. one isoleucine residue and one phenylalanine residue, which by analogy with other $\kappa \mathrm{I}$ chains may occupy positions 48 and 49 respectively. The failure to find in the tryptic digest the peptide occupying the positions 46-54 was probably due to a com- bination of two factors. One may be the poor reaction that the peptides obtained would give with ninhydrin, characteristic of peptides with valine or isoleucine as $N$-terminal residues; another may be the chymotryptic activity of the trypsin used, which produced, by incomplete hydrolysis, several peptides in low yield. There are three residues in the peptide (two of leucine and one of phenylalanine) that are highly susceptible to digestion by chymotrypsin. Chymotryptic cleavage in the tryptic digest is shown by the identical peptides TI-IIIN (Table 2) and TI-ICN3 (Table 3) coming from positions 93-96. The first was isolated from a tryptic digest, and the second after chymotryptic digestion, but both result from chymotryptic splitting.

The total amount of light chain used was $250 \mathrm{mg}$. It would have been very useful to have had $50 \mathrm{mg}$ more of protein Dee to repeat a tryptic digest with chymotrypsin-free trypsin, since it would have been easier to find a peptide of known composition. Unfortunately no more material was available.

Tryptophan residues were not determined, but the number deduced from the sequence (Fig. 5) is two, making the total number of residues/mol of light chain 214.

The variable region extends to residue 108 , as in other $\kappa$ chains.

Dee light chain has marked similarities with other $\kappa$ I light chains. Residue 24 is arginine and in other $\kappa$ I proteins this position is occupied by either glutamine or arginine. Arginine has been reported in proteins Eu (Cunningham, Gottlieb, Konigsberg \& Edelman, 1968), Ale, Car and Dee (Milstein et al. 1969), Ou (Köhler, Shimizu, Paul \& Putnam, 1970) and Hau (Watanabe \& Hilschmann, 1970). Some substitutions are only found in protein Dee and they are listed in Table $7(a)$. Table $7(c)$ shows positions in which the same variant residue occurs several times. The way in which these variants are linked in individual proteins is shown in Table 8. It appears that two groups of $\kappa \mathrm{I}$ chains can be distinguished. We have termed the first series of linked residues shown in Table $8 \kappa \mathrm{Ia}$ and the second $\kappa \mathrm{Ib}$. Proteins Roy and Ag have only one substitution and protein Bel two, when compared with the basic sequence $\kappa$ Ia. Similarly, in the second group, $\kappa \mathrm{Ib}$, proteins Dee and Ou have only one substitution and Eu two when compared with the basic sequence $\kappa \mathrm{Ib}$. Protein Bel shows more differences and this is also true of other parts of the molecule, since it presents ten different residues in the variable part when compared with the $\kappa \mathrm{I}$ basic sequence, whereas proteins Roy and Ag present only six differences. It is not possible to say whether these differences are of genetic or somatic origin. 


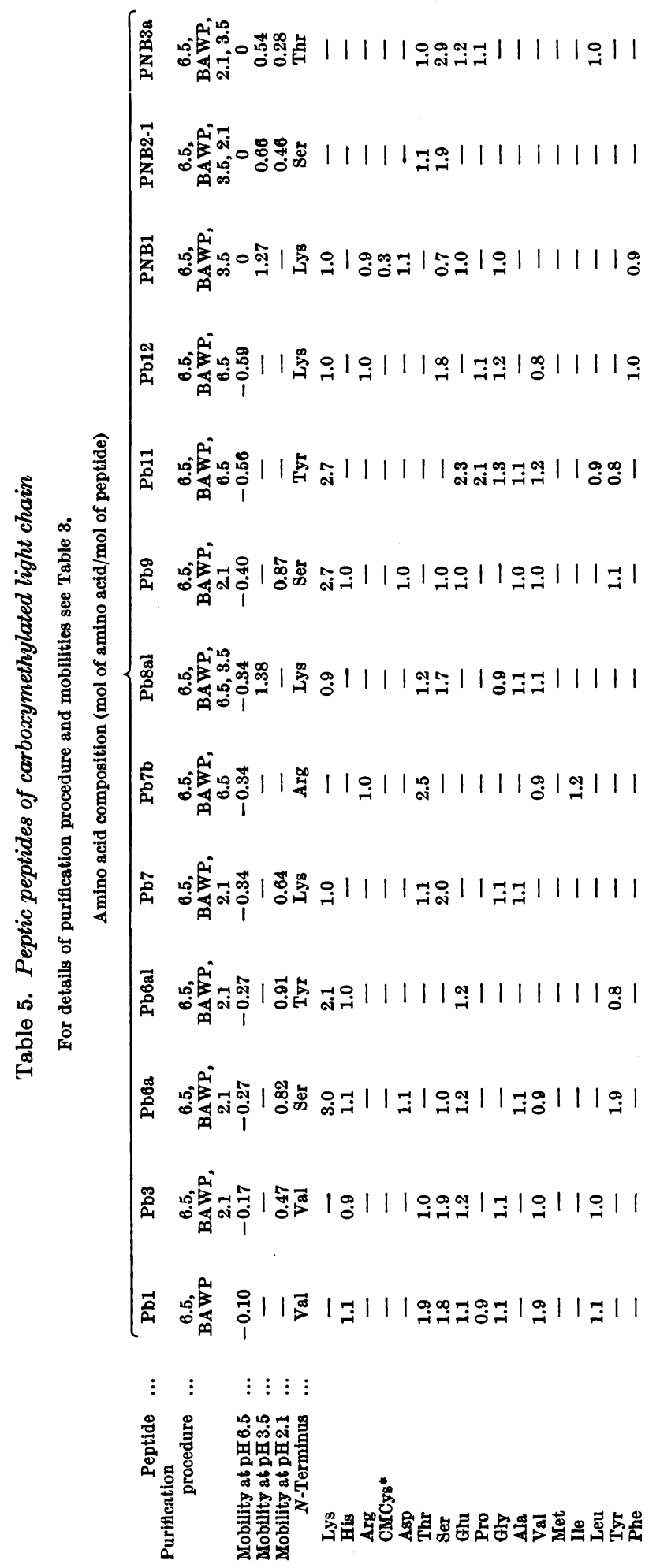




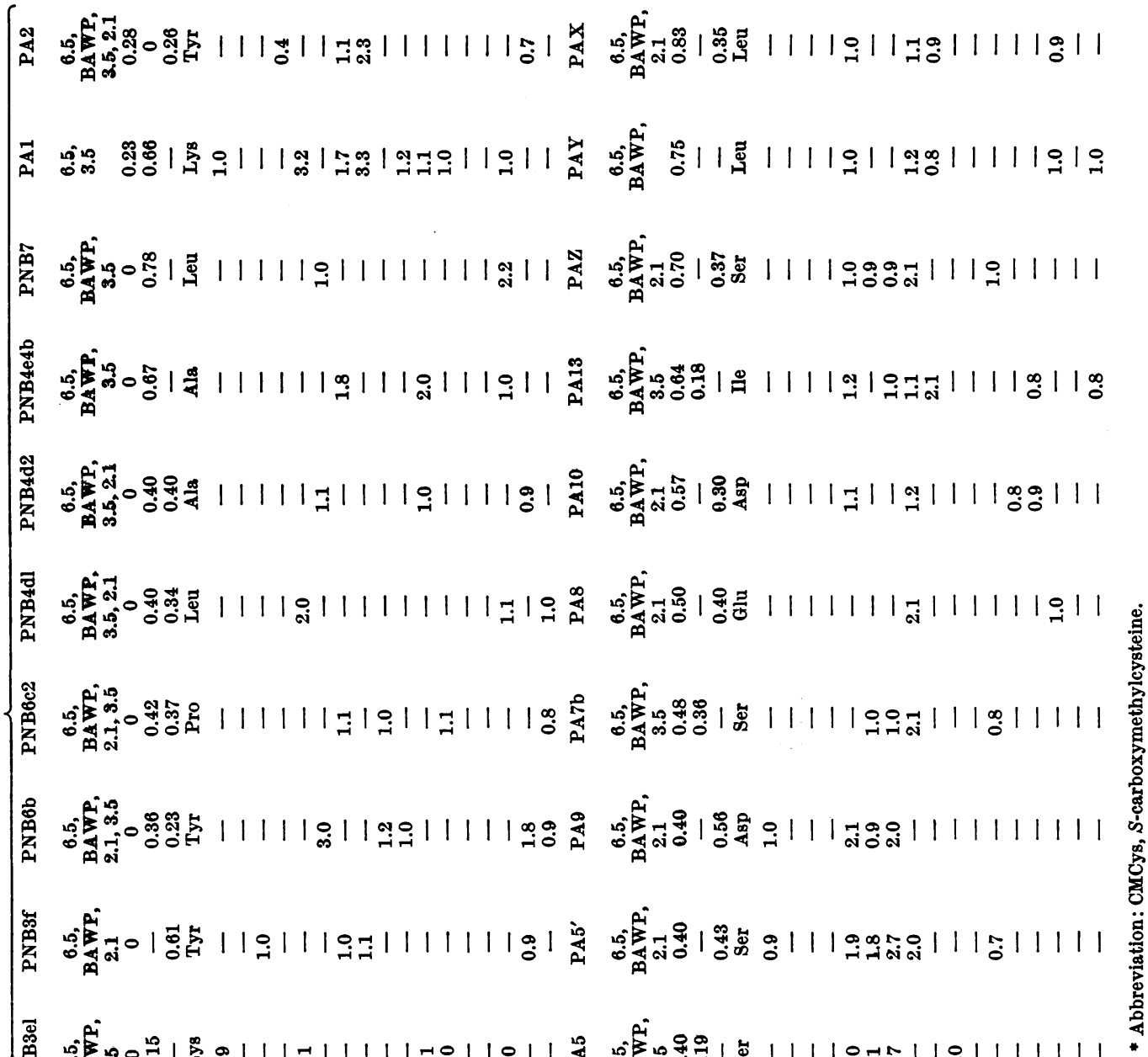

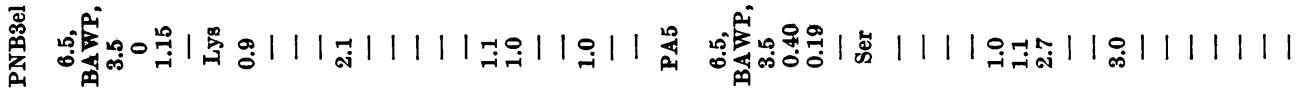

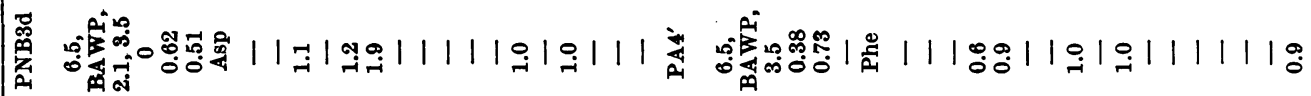

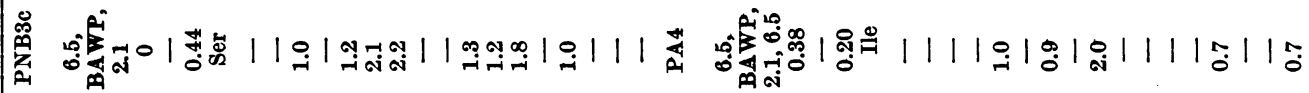
惫

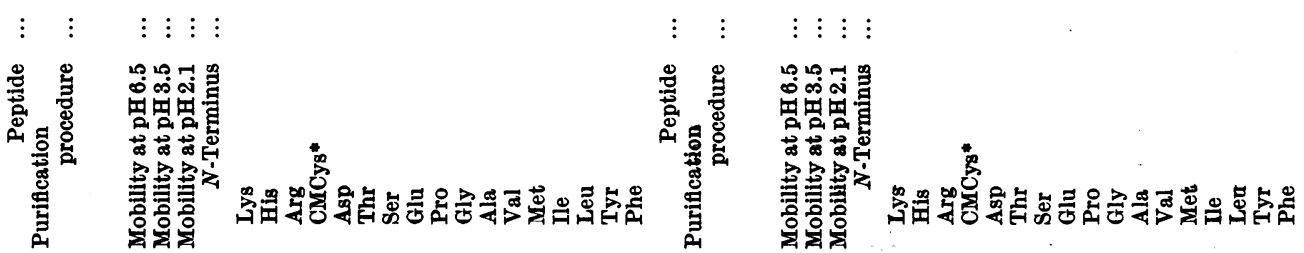



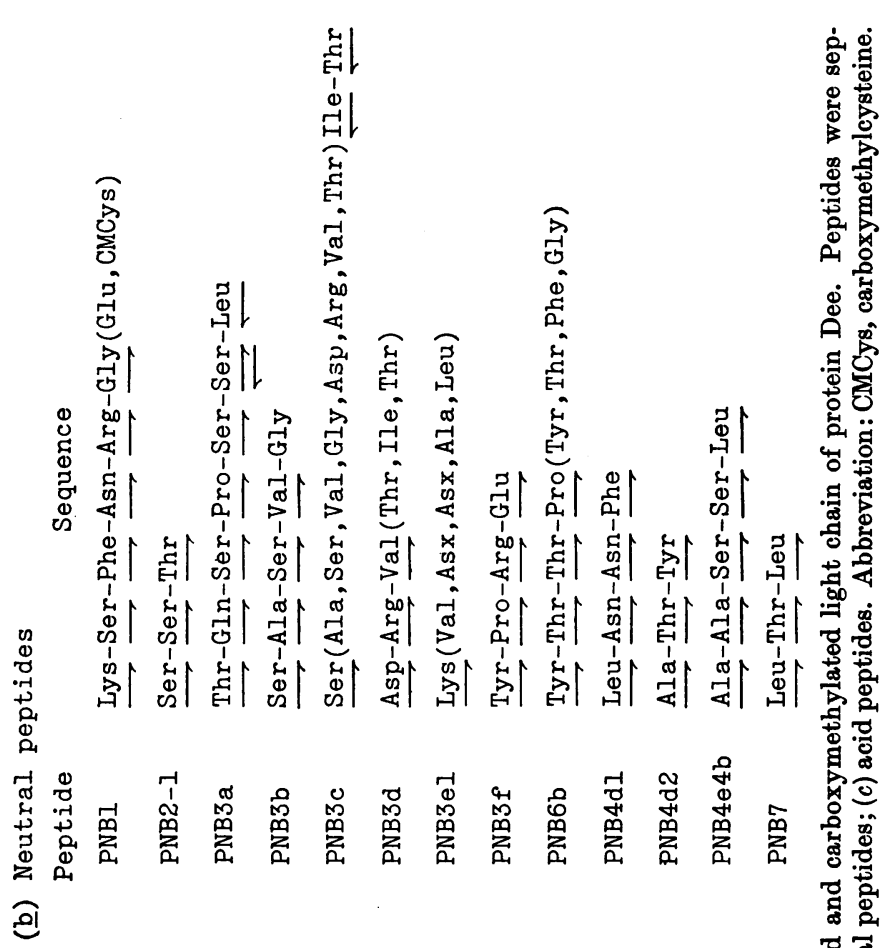

$n$
0
0
07
0
0
0
0
0
01 


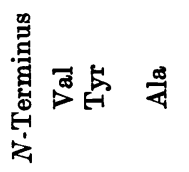

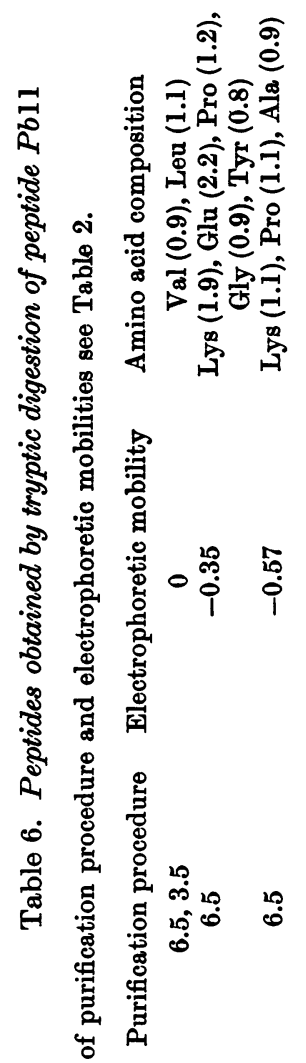

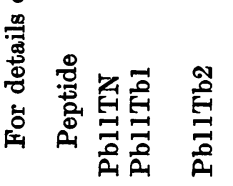

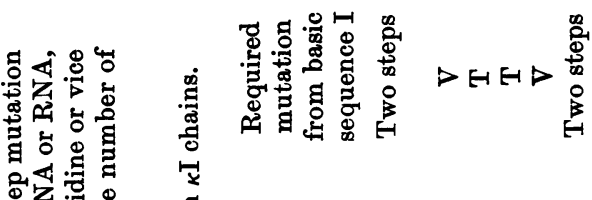

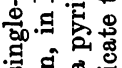

舟

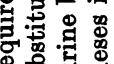

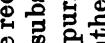

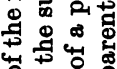

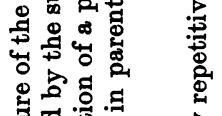

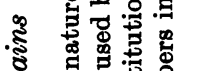

ริ

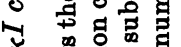

ई

है

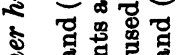

के ङ

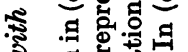

ร

รั้

요용

家

है

要



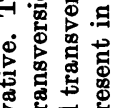

5

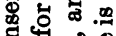

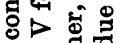

뭄

:

证。

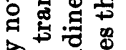

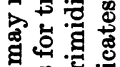

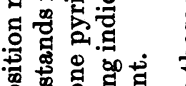

品

o

通密范范

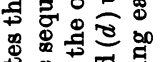

兽.

安氙。

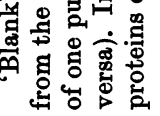<smiles>CPC[C@@H]1C[C@@H]2C[C@H]1[C@@H]2C</smiles>

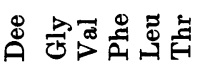

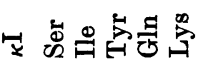

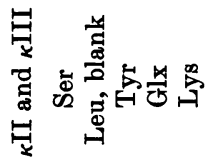

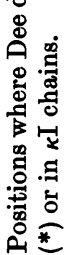

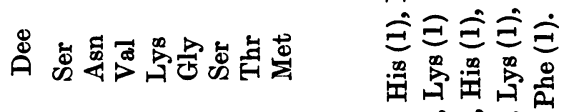

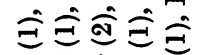

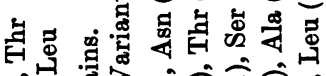

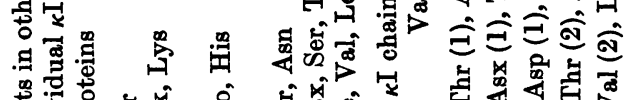

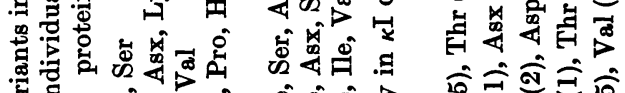

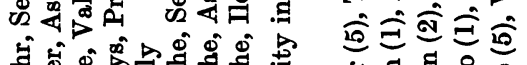
尊要要

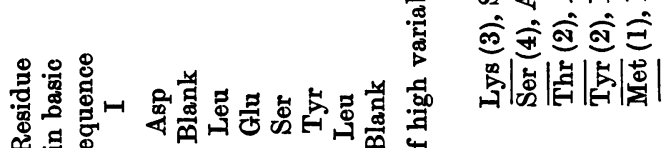

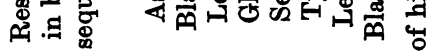

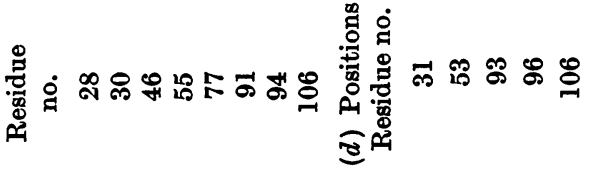

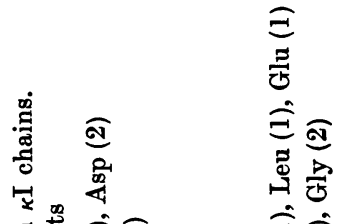

.

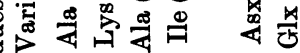

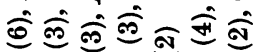

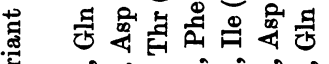

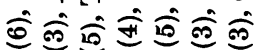

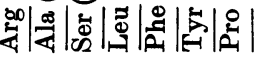
ह
语

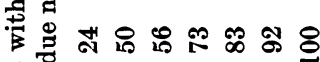


Table 8. Subgroups of $\kappa I$ basic sequence

The line means that the numbered residue of the protein and the basic sequence are the same. The line is interrupted when a difference occurs and the variant residue is included.

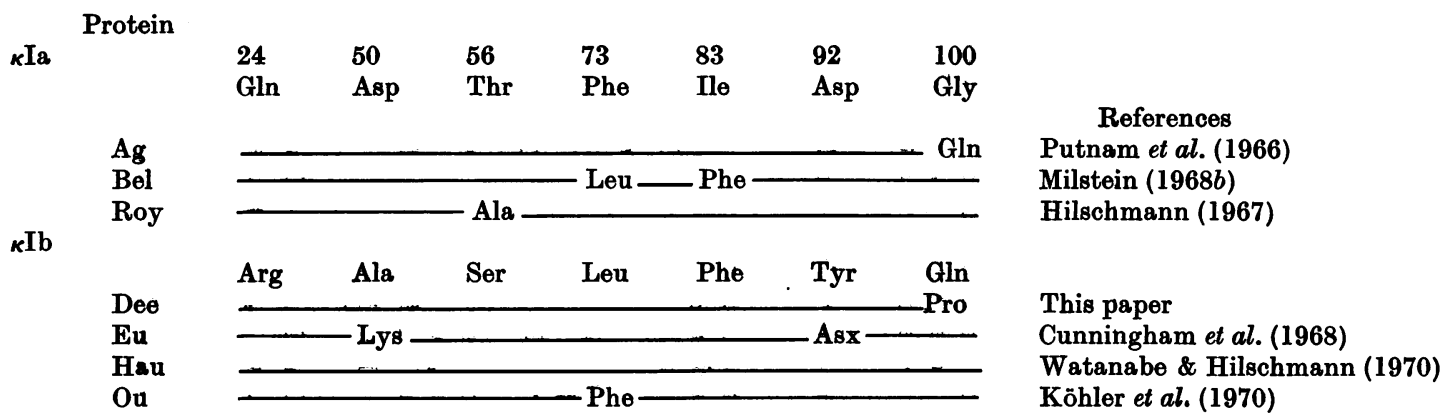

Glutamine and arginine occur at position 24 with about the same frequency but no evidence for alleles was found when the light chains of 17 normal individuals (now extended to 21 individuals; C. Milstein, unpublished work) were investigated (Milstein et al. 1969). Nothing can be said about the allelic or non-allelic nature of the other positions listed in Table $7(c)$ but since they appear linked to the arginine/glutamine substitution it seems reasonable to say that they define at least two different non-allelic genes. Among the positions listed in Table $7(d)$ residue 106 was included, although isoleucine might be considered as a residue of the basic sequence. This substitution has now been found as frequently as that at position 53, which together with positions 31,93 and 96 (Milstein \& Munro, 1970) were considered as highly variable ones and may contain the amino acids more directly responsible for the specificity of the antibody combining site (Kabat, 1968; Milstein \& Pink, 1970).

\section{REFERENCES}

Ambler, R. P. (1967). In Methods in Enzymology, vol. 11, p. 155. Ed. by Colowick, S. P. \& Kaplan, N. O. New York: Academic Press Inc.

Baglioni, C., Alescio Zonta, L., Cioli, D. \& Carbonara, A. (1966). Science, N.Y., $152,1519$.

Cunningham, B. A., Gottlieb, P. D., Konigsberg, W. H. \& Edelman, G. M. (1968). Biochemistry, Easton, 7, 1983.

Fleishman, J. B., Pain, R. H. \& Porter, R. R. (1962). Archs Biochem. Biophys. Suppl. no. 1, p. 174.

Gray, W. R. (1967). In Methods in Enzymology, vol. 11, p. 469. Ed. by Colowick, S. P. \& Kaplan, N. O. New York: Academic Press Inc.
Heilmann, J., Barrollier, J. \& Watzke, E. (1957). HoppeSeyler's Z. physiol. Chem. 309, 219.

Hilschmann, N. (1967). Hoppe-Seyler's Z. physiol. Chem. 348, 1077.

Hirs, C. H. W. (1956). J. biol. Chem. 219, 611.

Jepson, J. B. \& Smith, 1. (1953). Nature, Lond., 172, 1100. Kabat, E. A. (1968). Proc. natn. Acad.Sci. U.S.A. 59, 613. Köhler, H., Shimizu, A., Paul, C. \& Putnam, F. W. (1970). Science, N.Y., 169, 56.

Milstein, C. (1966a). Biochem. J. 101, 338.

Milstein, C. (1966b). Nature, Lond., 209, 370.

Milstein, C. (1968a). Biochem. J. 110, 652.

Milstein, C. (1968b). FEBS Symp. on Gamma Globulins, vol. 15, p. 43. Ed. by Franek, F. \& Shugar, D. London and New York: Academic Press.

Milstein, C., Milstein, C. P. \& Feinstein, A. (1969). Nature, Lond., 221, 152.

Milstein, C. \& Munro, A. J. (1970). A. Rev. Microbiol. 24, 335.

Milstein, C. \& Pink, J. R. L. (1970). Prog. Biophys. molec. Biol. 21, 209.

Milstein, C. P. \& Feinstein, A. (1968). Biochem. J. 107, 559.

Offord, R. E. (1966). Nature, Lond., 211, 591.

Porter, R. R. (1962). In Basic Problems of Neoplastic Diseases, p. 177. Ed. by Gellhorn, A. \& Hirschberg, E. New York: Columbia Unitersity Press.

Putnam, F. W., Titani, K. \& Whitley, E., jun. (1966). Proc. R. Soc. B, 166, 124.

Reindel, F. \& Hoppe, W. (1954). Chem. Ber. 87, 1103.

Sakaguchi, S. (1925). J. Biochem., Tokyo, 5, 133.

Spackman, D. H., Stein, W. H. \& Moore, S. (1958). Analyt. Chem. 30, 1190.

Watanabe, S. \& Hilschmann, N. (1970). Hoppe-Seyler's Z. physiol. Chem. 351, 1291.

Woods, K. R. \& Wang, K. T. (1967). Biochim. biophys. Acta, 133, 369.

Yamada, S. \& Itano, H. A. (1966). Biochim. biophys. Acta, 130, 538. 